\title{
Women and War - Conference at Harvard University's Center for European Studies
}

\section{Laura Lee Downs}

Columbia University

The mass wars of the twentieth century have abruptly overturned traditional gender roles in the effort to mobilize society most efficiently toward the goal of victory over the enemy. Scholars who have examined the long-range impact of the two world wars on gender relations have divided into two irreconcilable camps: those who have seen in these wars the foundations of new freedoms and priveleges for women, and those who conclude that the stresses of war on all segments of society generate a re-dedication to traditional feminine roles and encourage the re-assertion of patriarchal authority. The participants in Harvard's workshop on women and war, held in January, 1984, stated at the outset that their purpose in organizing the conference was "to move beyond this stalemate;" to acknowledge war as a critical moment in the history of gender relations, while attempting to construct new theroetical perspectives on the significance of these "moments" for the history of women. This purpose was pursued in sessions organized around four main themes: cultural expressions, political mobilization, social policy and the state, and the impact on personal life. While the discussion around each of these central themes ranged broadly, this review will highlight three matters of particular interest for the history of the working class.

Ruth Milkman's study of women workers and the CIO during the Second World War juxtaposes concepts of class unity with those of gender interest, exposing cycles of conflict and congruence between these distinct principles of political organization, and it shows how the evanescent conditions of war enabled a class conscious industrial trade unionism to act as a vehicle for the specific interests of women on the shopfloor. Her presentation, which focused on the United Electrical Workers and the United Auto Workers, concluded that "under the conditions which prevailed during the 1940 s, the only viable political ideology through which women could express their interests 'as women' in the industrial world was one of class unity (between women and men)." Feminism had no hope of succeeding in this period, and so the industrial unions, with their thousands of new female recruits, gave voice to the only calls for women's equality that were to be heard.

It was the desire to avoid the implantation of a cheap, unorganized workforce that first led the unions to approach women. Holding high the standard of equal 
rights, the male unionists sought to train women leaders and establish a definite place for women, activist and non-activist alike, within the structure of the existing male organization. This vigorous recruitment led, in turn, to union involvement in struggles for day care, transportation, aid with shopping, and other "out-plant" problems; to solidify links between women members and the union, and to free up women's time for greater union participation. The result was a rapid influx of women members, and a slight increase in women leaders as well.

However, the capacity of the CIO to thus "speak" for the interests of women workers diminished sharply after the war, bound up as it was with the temporary conditions of wartime employment. In 1946, management moved to oust women from the factories and to reconstruct the prewar sexual division of labor. Male members could then stand with management and opt for the maintenance of gender privilege, or act on the basis of a wider class interest and join the female activists in resisting postwar employment policies. With few exceptions, the voices defending male privilege shouted down the "women's rightists." The language of class solidarity, as spoken by the CIO in postwar America, no longer embraced the woman worker; she would have to seek another vehicle for the expression of her interests.

Milkman's talk was the only one to concentrate exclusively on working class history. In the course of discussion on other topics, however, several matters arose which bear significance for the conceptual and methodological points they raise.

The first issue concerned the conflicts between political agendas favoring motherhood and the family, and those favoring women's equality. Feminist scholars have long puzzled over the apparent resurgence of patriarchal authority which followed the efforts and achievements of thousands of Rosie the Riveters during the Second World War. Employers' persistent refusal to grant women equal rights to work, let alone equal pay and conditions, and society's evident collusion in this refusal, appears irrational and mean-spirited when viewed solely in the context of Rosie's many wartime sacrifices and accomplishments. But perhaps women's proven capacity to labor on a par with men in most sectors of factory and office work was not the most important consideration at the time. Papers given by Jane Jensen, Sonya Michel and Denise Riley all suggest that a powerful set of emotional appeals to motherhood and the maintenance of women in their critical role as the lynchpin of the family cut across the current of legislation favoring equal rights for women, and operated to circumscribe the practical impact of that legislation.

Jane Jensen examined the language of political debate in France during the liberation, focusing on the failure of the state to reconcile the two competing discourses on motherhood and equality, and on the consequences of that failure for the status and rights of women in postwar France. During the transition from Vichy to the Fourth Republic, the discourses on equality and on motherhood and the family developed simultaneously, yet proceeded without reference to each other. As a result, each discourse gave rise to its own legislative projects, and no attempt was made to reconcile the contradictory effects of these separately conceived programs. For a variety of reasons, the discourse built on the specificity of women's roles in reproduction and the family exerted a more powerful influence, and the 
categorical claim that the law guarantees to women rights equal to those of men in all spheres, found in the preamble to the Constitution of the Fourth Republic, was in actual fact hedged considerably by laws and practices which held women in a subordinate relation to their husbands. For example, legislators left intact the Napoleonic laws on marriage, which rendered married women dependent on their husbands for permission to take up employment outside the home. In addition, measures designed to improve working class living standards provided for wage supplements in the form of allocations paid out to the fathers of families. In this manner, working class women's economic dependence on men was reinforced by legislators and policy makers alike, who saw women primarily as mothers, subordinated to husbands in a traditional family structure. The cutting edge of equal rights legislation was thus dulled, even as traditional structures were strengthened by the developing welfare state.

Similar tendencies emerged in postwar Britain and America. Both Denise Riley and Sonya Michel traced the postwar demise of state-sponsored day care for working mothers, and linked the withdrawal of these facilities to the construction of ideologies which pathologized the working mother's "abandonment" of her children. If the rights of women to work were generally admitted, the rights of mothers to do so were certainly not. And since the political language used in the legislatures and bureaucratic offices spoke of women almost exclusively in terms of their maternal functions, the rights of women to employment were in fact more limited than they appeared on paper.

The second matter of methodological significance dealt with the limitations which surround the use of oral testimony in historical analysis. Historians sometimes quip that "history sets in the moment memory weakens." An acute sensitivity to the idiosyncracies of personal reminiscence characterized the final session on the impact of war on personal life. Annemarie Tröger's work interviewing women in the Berlin and Hannover oral history projects proved especially thoughtful and interesting in this regard. Her exploration of patterns of meaning in women's recollections of war underlines the fact that one cannot use oral histories without first understanding how those patterns of meaning have intervened to shape the individual's remembrance.

While interviewing the women of Hannover and Berlin, Tröger closely observed the structure and content of their largely self-directed life histories. To no one's surprise, the Second World War loomed large in the narratives, overshadowing all other experiences, including the seven years of National Socialist rule which preceded it. However, some unexpected patterns emerged when Tröger considered the nature of these war stories:

1) The war provided no more, and often far fewer stories than other periods in these women's lives, yet stories from this limited repertoire were retold several times, particularly in interviews which stretched out over several sessions.

2) The recollections of this time are "somehow gray, impersonal and distant, as if they themselves did not really live through it." This was especially true of the most 
frightening and dramatic phase of the war, the period of heavy bombardments in the final year and a half.

3) In many war-related accounts, Tröger observed a "compositional character" in the narrative, that is, individuals took incidences, circumstances and persons which may have been present in a series of similar but temporally distinct situations, brought them together and recomposed them into a single dramatic narrative. In this recomposition, Tröger sees a specific transformation taking place, in which the factual historical significance of the events being recounted recedes as the speaker constructs "higher, quasi-symbolic meanings" for them.

The fascination of Tröger's work lies in her discovery and interpretation of these quasi-symbolic meanings, woven by individuals from their own personal experiences, yet bearing collective patterns of meaning which have yet to be socially codified. The fact that war experiences are reconstructed and related in this symbolic fashion indicates that at some level, people clearly intend to convey something beyond the mere factual account; perhaps a deeper message about "senseless and nameless death in a de-personalized warfare, in which human life - one's own life - has no value, not even for oneself." Whatever the conscious level of intent in thus mediating one's own experiences, the implications for scholars relying on oral histories are clear. Mining the recollections of the living offers historians a wealth of information about the individual and her experiences, but at present, historians are probably not equipped to bridge the gap which yawns between memory and historical analysis.

While one could not fairly state that this conference succeeded in moving us beyond the stalemate, the seeds of a possible solution were present. Adhering to the current wisdom, participants leaned toward the conclusion that war encourages the re-assertion of patriarchal authority. However, the broad-ranging discussions suggested that the mere invocation of a resurgent patriarchalism does not begin to explain this complex issue. Indeed, the discussions reinforced my impression that war engenders a sequential interplay between forces toward liberation and forces toward patriarchy. Accordingly, it is my view that there can be no satisfactory explanation of the impact of war on gender relations until the stalemate is broken, until the adherents of both factions pool their collective insights to develop a theory which explains such interplay.

The complete list of papers given at this conference runs as follows: Sandra Gilbert, "Soldier's Heart: Literary Men, Literary Women, and the Great War;" Susan Gubar, "Charred Skirts and Deathmask: World War II and the Blitz of Women;" Andrea Walsh, "Of Strong Mothers and Terrified Wives: World War Il and the Hollywood 'Women's Film;' " Renate Bridenthal, "National Feminism, A Contradiction: The German Case in World War I and After;" Steven Hause, "More Minerva than Mars: The French Women's Rights Campaign and the First World War;" Ruth Milkman, "American Women and Industrial Unionism during World War II;" Paula Schwartz, "Observations on the Specificity of Women's Role in the 
French Resistance;" Karin Hausen, "The Nation's Obligations to the Heroes' Widows of World War I;" Jane Jenson, "The Liberation and New Rights for Women;" Sonya Michel, "Patriotism and Professionalism: Social Services for American Working Women in World War II;" Denise Riley, "The Peculiarities of Women as Objects of Social Policy, World War II in Britain;" Lynne Layton, "Vera Brittain's Testament;" Annemarie Tröger, "Experience/Memories/Images of War: Oral Accounts of World War II by Women in Berlin and Hannover;" Margaret Weitz, "Self-Discovery of Women in the French Resistance." 